\title{
Evaluation of Chinese E-Commerce Cost and Lead Time Performance to Estonia
}

DOI: 10.12776/QIP.V22I1.1035

\author{
Olli-Pekka Hilmola, Andres Tolli
}

Received: 17 November 2017 Accepted: 25 January 2018 Published: 31 March 2018

\begin{abstract}
Purpose: Retail sales growth has been sluggish in the recent decade in North European countries. Number of factors have caused this, like problems in macroeconomy, sanctions and the effect of ageing population. Also increasing amount of e-commerce from China has taken its share. Future development paths need to be researched further to identify the outlook of North European retail.
\end{abstract}

Methodology/Approach: Four different imported items were examined, which were hypothetically planned to be brought on Estonian consumer markets from China. We take into account freight costs, custom duties, VAT and profit margin requirement. Also lead time performance is being examined.

Findings: Analysis shows that company based imports is not that viable model as profit margin requirement as well as governmental costs (duty and VAT) take lion share from overall costs. Even if profit requirement of company importing the products would decrease, wage inflation in Asia and freight will probably lead to higher product prices. Therefore, e-commerce needs to enlarge to lower cost manufacturing locations and/or use more direct sales to consumers. Total lead time soughts new solutions too (e.g. railway connection to Europe).

Research Limitation/implication: Examination is limited to small Estonian market, and their custom tariffs and VAT. Also logistics costs to Northern Europe are higher than to Central Europe.

Originality/Value of paper: Research is one of the first based on the examination of products and overall costs. It adds value through understanding of import cost structures.

Category: Research paper

Keywords: e-commerce; business-to-business; business-to-consumers; total costs; lead time; transportation 


\section{INTRODUCTION}

Development of e-commerce has been stormy in recent years globally, and especially in China. Online shopping is one of the most popular online activities, but the usage varies by region - in 2016, e.g. it was estimated that 19 percent of all retail sales in China were completed via internet. In 2016, e-retail sales accounted for 8.7 percent of all retail sales worldwide. This figure is expected to reach 15.5 percent in 2021. In 2016, retail e-commerce sales worldwide amounted to 1.86 trillion US dollars (The Statistics Portal, 2017; similar findings, Deloitte, 2017). Main issue in e-commerce is that prices (Zhao, et al., 2008), assortment, and availability differ greatly between different actors. This of course increases the excitement and human time spent on online markets.

In Estonia, there are companies for instance Omniva and Febest Europe Distribution together with international ecommerce giants like AliExpress, eBay and S.F. Express, which are developing additional warehousing capacity especially for e-commerce (e.g. Reimer, 2015). Preparation of post-hubs in order to accelerate up transportation of e-commerce goods for clients in Europe and Russia. According to this strategy, the e-store will send the most popular items, like mobile phones etc. to the warehouse in advance. As a client in Europe files an order, she/he gets the item from Estonia in two days, instead of having to wait for 30 days for a parcel all the way from China. Similar kind of local warehouse configuration is present in Finland for company selling mostly Chinese electronics (warehouse in Finland for short lead time shipments on some limited set of items). This distribution strategy arises from practices out of Chinese markets, where delivery of an online product is promised to be shipped in hours or next day (like JD.Com introduced years ago, see Yu, et al., 2016).

Booming e-commerce also supports shipping lines and development of the container flows through ports and container terminals. Usually most of the ecommerce commodities have been shipped out from Asia, especially from China to Europe and USA.

Leading online shopping models, and consumer interaction is also arising nowadays from China, like Single's day, which is breaking world records in hourly transactions, and is greatly supported by the desire of shoppers to follow others e.g. through sales volume statistics, online ratings and customer comments (Xu, et al., 2017).

The growth of containerization and transporting goods in containers has created many challenges for the container terminals. To meet these challenges, the container terminals have to innovate and optimize their logistics processes (Rashidi and Tsang, 2016). In practice, ports of all the other countries at the Baltic Sea are competing additionally from export-import flows for easterndirected transit container flows as prospective growth is the highest there. Today also container penetration in Russia remains fundamentally low and this also supports containerization growth in the Baltic Sea region totally (Sorgenfrei, 2013; Global Ports, 2012). 
At the same time, Russia is aggressively developing its container terminal capacities mainly in St. Petersburg, Ust-Luga and Bronka. Therefore, in the container flows it could be predicted for the coming years, that Russia-directed container flows will have a key share and will be growing year by year. However also Port of Gdansk and Port of Klaipeda are developing rapidly due to direct container calls from China and other Asia states into these ports and both are already region gateway ports. Direct call has several advantages in relation to deep sea and short sea transport. Deep sea and short sea transport is more expensive compared to direct call. Chinese container flows constitute a large portion of container flows on the global container transport. Many world seaports compete for Chinese container flows and make their efforts to acquire investments and direct calls from China to their ports (Tolli, 2008). Shipping lines like Maersk are doing strategic cooperation with Alibaba to allow customers to reserve space on its vessels through Chinese company, supporting growing cooperation between e-commerce and logistics companies. However, it should be noted that in many studies lead times are seen as one of the most challenging issue to be resolved, and this does not only concern transportation, but also manufacturing at low cost location (Kumar and Arbi, 2007; Zhang and Huang, 2012; Salam and Khan, 2016).

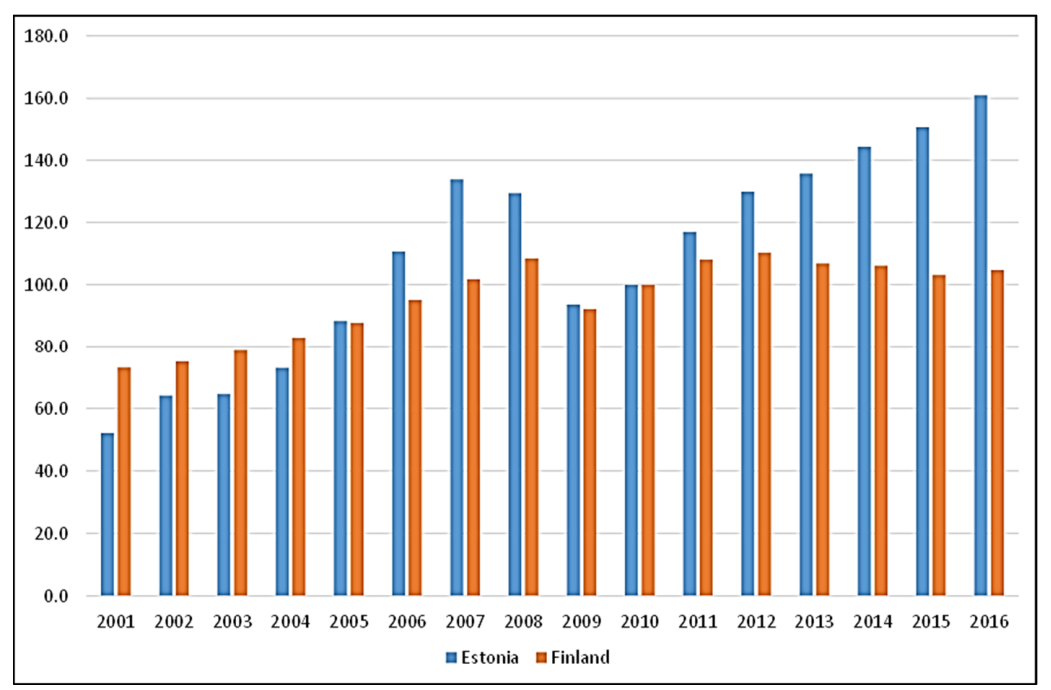

Figure 1 - Retail Trade (in Finland series with wholesale, in Estonia without it) Development (nominal) in Estonia and Finland During Period of 2001-2016 (year $2010=100$ ) (Source: Statistics Estonia, 2017; Statistics Finland, 2017)

Challenging environment of retail trade in Estonia and Finland is illustrated with revenue development of this sector in Fig. 1 (years 2001-2016). Macro-economic crises of 2008-2009 (USA) and 2010-2013 (Europe) could be accessed in revenue development. Actually, Finnish development is still rather sluggish, even if this revenue data does not consider inflation development (in the case of 
Finland it has been rather conservative, around 1-2\% after year 2009). It is not surprising to find out that Finnish retail market development was in the group of the worst during the years 2014-2016 among EU-28 countries (Doplbauer, 2015, 2016; Hille, 2017). Estonian retail market has been performing a bit better, however, it should be noted that inflation has been double to that of Finland. Based on European wide studies Estonian retail has shown one of the strongest growths among EU-28 countries in 2014-2016 (Doplbauer, 2015, 2016; Hille, 2017). Both of these countries of course experience the effect of ageing population, where consumption typically has tendency to decline. Both countries were strong in domestic retail before the macro economic hardship experienced. Part of lacking growth in retail could be argued to belong on increased ecommerce, which has been completed by people themselves from abroad directly to their home. In here countries like China, USA, Germany and UK play important role.

Research problem of this work is related to the competitiveness and the role of intermediaries in retail business, in this case brick-and-mortar retailers and wholesalers in Estonia. Interest in examination is in China, and import products from this country to Estonia. Following research questions operationalize this study: 'What is the cost structure of imported product from China as it includes all the costs in order to be sold in Estonian consumer market?', 'What kind of role customs, taxes and logistics costs have on the overall costs?, and 'What is the competitiveness of brick-and-mortar business vs. direct e-commerce shipments?'.

\section{GROWTH STORY OF ALIBABA}

Chinese technology sector development has been largely ignored in west as being rather similar to innovations made already in North America and Europe. However, things have changed a lot in recent years. For example, when Alibaba listed itself through IPO to New York Stock Exchange, it received a lot of cash to grow in the following years. Even in most recently quarterly report available, ending to June (Alibaba, 2017), company reports to hold more than 21 bill. USD as cash. Situation has remained similar since IPO as Alibaba has been consistently growing in revenue and profit terms - cash position has been nurtured carefully. With around 30\% operating margin, it easily over qualifies comparison group of leading North American e-commerce companies (like Amazon or eBay). What is exceptional in Alibaba, and many other Chinese multinationals, is the ability to offer customer value with price competitive overall package (Chakravarthy and Yau, 2017). Hänninen, et al. (2017) also noted in their case study of four large-scale and international e-commerce companies following: Alibaba was having lowest commissions asked within the comparison group, but also largest customer base and amount of revenue.

Fig. 2 illustrates further revenue development and return on investment during recent years. Alibaba has been growing and showing profits in the same time - 
this is very untypical setting. Situation has remained as such during year 2017. Current market valuation of Alibaba is around 450 bill. USD - it is just huge company, if thinking about future prospects of investors regarding growth.

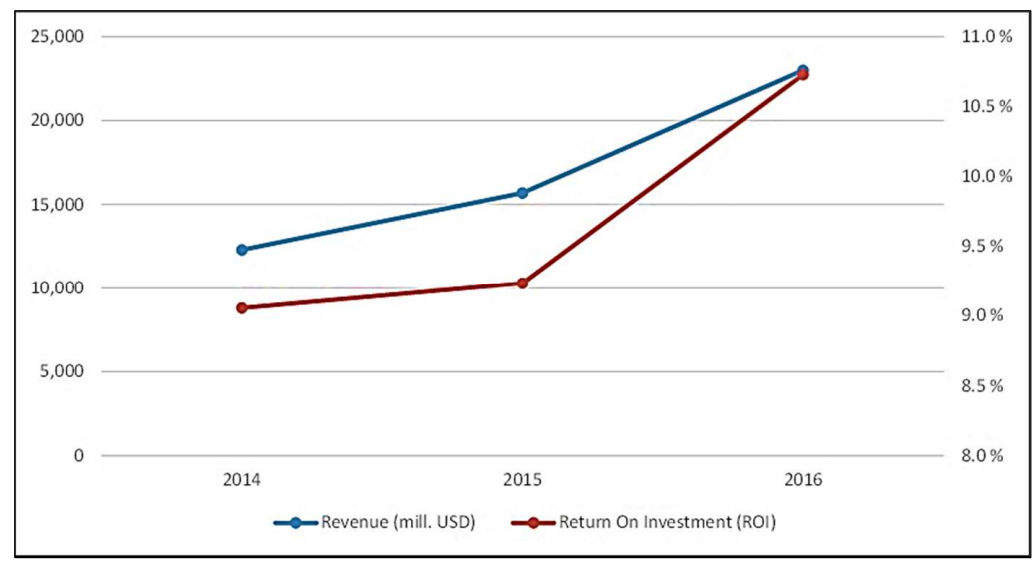

Figure 2 - Alibaba's Revenue (in mill. USD) and Return on Investment (\%) Performance during Years 2014-2016

(Source: Annual Reports)

Business of Alibaba is not small scale anymore. As Economist (2017) points out, it currently handles more transactions per year than eBay and Amazon combined. Its goal is to reach 2 billion consumers in the next two decades (Economist, 2017). Business model of Chinese e-commerce companies (or technology companies) is different from west, as in Chinese model idea is to integrate much of the business in both horizontal and vertical terms (Economist, 2017; Chen, 2016). During the recent years' Alibaba has acquired companies such as Autonavi (maps), Intime Retail Group (China, traditional retail), Beijing Chuanyun Logistics, Singapore Post, Shanghai First Financial Media, South China Morning Post (newspaper), Didi Chunxing (ride sharing), Ele.me (food delivery service in China), Lazada (e-commerce in Southeast Asia), Youku Tudou (video streaming in China), and Lyft (ride sharing). Some of these companies are entirely owned by Alibaba, or in major parts. It should be remembered that one of the most important parts of Alibaba is its Alipay wallet and payment system - it is hugely popular in online commerce payments in China, and is expanding now to new markets such as Europe. It is also cheap way to have own small savings account, stored in Internet based wallet.

Alibaba is of course having most of its revenues and profits coming from diverse operations in China and Asia, but European expansion is on the agenda (and has been for years). Bury (2017) speculated that Alibaba would be keen to expand its European warehouse network based on railway corridor connections built in recent years between China and Europe (like trains serving Spain, UK, Poland and Germany). Bury (2017) reports that current warehouse network is not significant, one in UK and another one under planning to Bulgaria. Of course, 
company is having numerous partners, through which it can distribute products widely and safely throughout the Europe. One of such partners is Finnish Post, which will take care of some share of shipments to Russia (Virtanen, 2015).

\section{EVALUATION OF COSTS AND LEAD TIME TO REACH ESTONIAN MARKET}

For the purposes of evaluating the competitiveness of Chinese e-commerce, in the course of "Transport and Warehouse Logistics" students (third year course in Estonian Maritime Academy, Tallinn University of Technology, Estonia) were asked to select product out of Alibaba e-commerce platform to be imported to Estonia. We selected Alibaba instead of AliExpress as it is merely targeted for the use of "business-to-business" transactions, and it contains information about minimum order quantities, lead times, supply locations, and maximum capacity. In the following all logistical costs were estimated with Alibaba Logistics (2017) website from where students were asked to select most convenient one for their import purposes (students groups were asked to evaluate three alternatives: full container and less than container load using sea transports as well as air freight). Destination in all of the transportation price estimates was Tallinn, Estonia. Transportation costs included insurance for the cargo. Research method in the following is quantitative case study (Ellram, 1996; Voss, et al., 2002; Eisenhardt and Graebner, 2007) out of Alibaba retail platform, which is based on publicly available second-hand data from number of different sources. This case study of four products resembles key points of importing items from China to Europe.

As importing items from outside of European Union area, importers are subject to customs payments. These were estimated with the help of Estonian Customs (2017) website, from where students searched duty class for their product, and estimated duty amount with the total cost, including purchase price and freight transportation costs to Estonia. Value Added Tax (VAT) was also estimated in this phase, but it does not have larger role in final evaluation as paid VAT in this phase could be deducted from VAT gathered in sales phase. Typical VAT percentage in Estonia is $20 \%$. Custom duties of course are dependent, what kind of items are being imported, but in products of Tab. 1 they were around 6-10\%.

For product pricing estimates, it was used margin of $70 \%$ in imported product. Above this requirement and all the costs taken into account, were added VAT of $20 \%$. Some might argue that $70 \%$ is too high margin for imported product, but in here we have only direct product costs taken into account (as imported to Estonia), and product sales need to cover such cost items as rent of retail space, salaries, utility costs, capital costs, spoilage, warranty costs, and overhead. As reference to $70 \%$, we could give $\mathrm{H} \& \mathrm{M}$, which has been operating with "gross margin" of around $60 \%$ for many years.

As evaluating the role of freight costs in overall costs (Tab. 1), it was rather surprising to note that even LCL sea container and air freight were working 
rather well, and in worst case freight costs were slightly above $8 \%$ (products 1 and 4). If full container is used, sea freight costs were really low as product 2 illustrates. Even if item price and freight cost seems to be low (as compared to VAT price), they are very important elements on cost competitiveness as custom duties, profit margins and VAT are calculated based on these two costs.

What was interesting to note during the student work completion process, was of course the long delay of sea transportation (which has been well documented in earlier research), but also time needed to manufacture products. Not all sold products are manufactured with principle of "make to stock", but rather on mode of "assembly to order" or "make to order". Most expensive product 4 took 30 days to manufacture and being available in Chinese sea port. It of course is case dependent, what is the overall lead time, but manufacturing and transportation delay together is around 60 days, if sea transportation is used. Air freight could help in here, but in case of product 4 total lead time is still at least 35 days.

What was also notable in student works, was the recommended order lot size of products. It was asked for them to calculate also Economic Order Quantity (EOQ), but this was seldom order quantity. Higher order quantities were preferred simply because of filling e.g. container to some appropriate level and/or making larger order due to long lead times to wait for other deliveries. These reasons could be causing excessive inventory holdings in real-life situations too also decreasing the attractiveness of large-scale e-commerce from China in "business-to-business" setting.

Table 1 - Four Products, and Their Price at Chinese Location, Estimated Final Price in Retail Market (with Value Added Tax of 20\%), Freight Costs, Transportation Mode Selected, and Lead Times

\begin{tabular}{|l|c|c|c|c|c|c|}
\hline & $\begin{array}{c}\text { Item } \\
\text { price } \\
\text { in EUR }\end{array}$ & $\begin{array}{c}\text { Imported Item } \\
\text { Price (with } \\
\text { VAT) in EUR }\end{array}$ & $\begin{array}{c}\text { Freight } \\
\text { costs }\end{array}$ & $\begin{array}{c}\text { Transportation } \\
\text { Mode }\end{array}$ & $\begin{array}{c}\text { Manufacturing } \\
\text { Lead Time (d) }\end{array}$ & $\begin{array}{c}\text { Transportation } \\
\text { Lead Time (d) }\end{array}$ \\
\hline Product 1 & 5.53 & 15.17 & $8.20 \%$ & $\begin{array}{c}\text { LCL sea } \\
\text { container }\end{array}$ & 16 & 46 \\
\hline Product 2 & 0.19 & 0.89 & $2.24 \%$ & $\begin{array}{c}\text { FCL sea } \\
\text { container }\end{array}$ & 20 & 46 \\
\hline Product 3 & 0.30 & 1.60 & $3.98 \%$ & $\begin{array}{c}\text { LCL sea } \\
\text { container }\end{array}$ & 15 & 45 \\
\hline Product 4 & 6.60 & 38.23 & $8.82 \%$ & Air Freight & 30 & 5 \\
\hline
\end{tabular}


Table 2 - Breakdown of Cost Structure of Imported Product 2

\begin{tabular}{|l|r|r|}
\hline Item & Sum in EUR & Share \\
\hline Product purchase price & $9,500.0$ & $21.2 \%$ \\
\hline Custom duties & 682.6 & $1.5 \%$ \\
\hline Transportation & $1,001.7$ & $2.2 \%$ \\
\hline Profit $(70 \%)$ & $26,096.8$ & $58.3 \%$ \\
\hline VAT $(20 \%)$ & $7,456.2$ & $16.7 \%$ \\
\hline Total & $44,737.2$ & \\
\hline
\end{tabular}

From product cost perspective it is important to note that actual product price, and transportation typically cover around $20 \%$ from final product total costs (like product 2 in Tab. 2). Biggest share of product costs goes to importing company profit and cost requirements, and to governmental costs such as custom duties and VAT (see Tab.2). Even if in the future margin taken by importing company would decrease to $50 \%$ (or that of $30 \%$ ), it could be so that items acquired from Asia get much higher priced due to growing salaries, appreciating currencies, and other costs. Therefore, in the future role of importing company (wholesaler and/or retailer) would just decrease, but other cost classes would increase. It is notable that driver of other cost classes is the acquisition costs of sold product, and the acquisition costs to final destination. If these together will increase, so will custom payments, and possibly VAT (last one depends on overall costs). Tab. 3 illustrates situation further, where actual product price increases by $100 \%$, and profit requirement of importing company decreases to 30\% (other factors remaining as the same from Tab. 2).

Table 3 - Breakdown of Cost Structure of Imported Product 2, in Hypothetical Future Situation, When Product Price Increases by 100\% and Profit Margin Requirement of Importing Company Is Only 30\%

\begin{tabular}{|l|r|r|}
\hline Item & Sum in EUR & Share \\
\hline Product purchase price & $19,000.0$ & $30.5 \%$ \\
\hline Custom duties & $1,365.2$ & $2.2 \%$ \\
\hline Transportation & $1,001.7$ & $1.6 \%$ \\
\hline Profit (30\%) & $30,524.2$ & $49.0 \%$ \\
\hline VAT $(20 \%)$ & $10,378.2$ & $16.7 \%$ \\
\hline Total & $62,269.40$ & \\
\hline
\end{tabular}

In this potential future scenario, overall costs on the shop shelf of the product shall increase by $39.2 \%$ (as comparing total costs of Tab. 2 and 3). In import of product 2 transportation costs are really low due to the use of full containers, and therefore also transportation element contains pressure to increase in the future 
(mostly due to historically low container transport rates of sea vessels). Due to this, it is reasonable to assume that Chinese manufacturing (and Asian manufacturing) shall seek new low cost places from areas not being so overheated - one example is the manufacturing expansion in Central and Western China. From this new location perspective, it is also important to develop other transportation routes than sea transportation or air freight. By utilizing these "old" solutions, transportation lead times ought to increase even further, leading to excessive inventory in the logistics system.

E-commerce also plays important role in the further growing exports from new manufacturing locations, and also old ones. However, based on Tab. 2 and 3, this is not necessarily smart to execute through business-to-business sales. Middleman, or in other words local importing company, needs to be removed from equation, if cost pressure is desired to be managed. Therefore, growth of ecommerce from Asia to Northern Europe based on this short analysis ought to come from business-to-consumer type of sales.

Table 4 - Breakdown of Cost Structure of Imported Product 2, in Hypothetical Future Situation, When Product Price Increases by 100\% and Middle-Man Is Removed from Supply Cost Structure (Directly from China to Consumer)

\begin{tabular}{|l|r|r|}
\hline Item & Sum in EUR & Share \\
\hline Product purchase price & $19,000.0$ & $74.1 \%$ \\
\hline Custom duties & $1,365.2$ & $5.3 \%$ \\
\hline Transportation & $1,001.7$ & $3.9 \%$ \\
\hline VAT $(20 \%)$ & $4,273.39$ & $16.7 \%$ \\
\hline Total & $25,640.30$ & \\
\hline
\end{tabular}

Effect of removing middle-man from increasing cost situation could be seen in Tab. 4. Total costs will decrease by $42.7 \%$ from the original situation, where manufacturing was still cheap in Asian location, but there were local retailer having own profit requirement. In practice saving potential is not as high as transportation solution is in any case more costly for single consumer ordering product to their home. It is also doubtful whether product prices can remain as low as for bulky orders of larger retailers. In addition, global e-commerce needs to develop custom routines for ordinary customers more convenient in order that this approach will spread as more common among larger population.

\section{CONCLUSIONS}

When IT-boom was heating on during the late 1990's, world saw the first e-commerce shops to open, for both business-to-business and business-toconsumer markets. These portals were typically concentrating on some very limited product groups, like books and/or music CDs. A lot has happened 
thereafter. New changes will take place, as consumer direct model will become more common in long-distance sales. For example, in Europe people are increasingly going online, and they are shopping e.g. directly from China. This is already present in retail sector as it is difficult for "brick-and-mortar" companies to sustain and be profitable. We have witnessed many bankruptcies in USA/North America, but also in Europe due to this (especially in Finland some very large-scale chains have just disappeared). Numerous iconic retailers in both side of Atlantic are in big trouble.

Based on the analysis completed in this work, current import from China at retail shelves contains a lot of governmental customs and taxes as well as profit, overheads and operative costs of retailers/wholesalers, and actually manufacturing and logistics costs are minority. However, this could change in the forthcoming years as Asian economies start to dominate within group of larger economies of the world, and their currencies will appreciate. Especially in this situation of growing manufacturing costs, analysis of this research work showed that direct ordering from China by individual without middlemen is clearly economically justified, and results in huge savings within overall costs. This direct model can tackle coming inflationary price increases, however, it will mean troubles for brick-and-mortar wholesalers/retailers as well as partially for local government in terms of lower tax gatherings (VAT, as this tax is based on final price paid in the market, and prices will be lower at border).

In this research work, we were interested mostly about Estonian market. Retail sector has been one of the healthiest in Europe in this country, and new malls as well as shops have been opened in recent years. We do not see the business of shops selling cheap Chinese items as long-term and sustainable strategy. Merely, shops should specialize and sell increasingly local or regional products (or bundle services to product sales). As "consumer direct" model will spread around further, growth and profitability of Asian import based local retail model will face difficulties. It already is doing so (Deloitte, 2017). During the exercise of Section 3 of this paper, we checked with students, the pricing of products planned to be imported. It was in many cases the situation that price of product to be imported was around estimated price with $70 \%$ margin or it was somewhat below it. This only further indicates that companies are trying to achieve such high margins, but it is of course difficult to do so.

For logistics sector, e-commerce makes rules and life a little bit different. Companies, shipping lines, warehouses and hinterland transports should transform themselves to serve small parcel deliveries, instead of delivering large lot sizes. This is difficult task to be completed with profits. New technologies and techniques need to be implemented. However, for logistics sector this path must be taken as growth e.g. in container transports is very limited in the following decade. 


\section{REFERENCES}

Alibaba Logistics, 2017. Alibaba Logistics buyer portal to select transportation mode. Available at: <https://logistics.alibaba.com/buyer.htm> [Accessed 4 October 2017].

Alibaba, 2017. Alibaba Group Announces June Quarter 2017 Results. [pdf] Hangzhou, China: Alibaba Group. Available at: $<$ http://www.alibabagroup.com/en/news/press_pdf/p170817.pdf $>$ [Accessed 23 October 2017].

Bury, R., 2017. Alibaba targets Silk Road train route for European push. The Telegraph, [online] 17 April. Available at: <http://www.telegraph.co. uk/business/2017/04/17/alibaba-targets-silk-road-train-route-european-push/> [Accessed 23 October 2017].

Chakravarthy, B. and Yau, D., 2017. Becoming global leaders: innovation challenges for five large Chinese firms. Strategy \& Leadership, [e-journal] 45(2), pp.19-24. https://doi.org/10.1108/SL-02-2017-0014.

Chen, L.Y., 2016. Alibaba's shopping spree: How the web giant's universe has expanded. Bloomberg News, [online] 13 December. Available at: $<$ https://www.bloomberg.com/news/articles/2016-12-13/alibaba-s-shoppingspree-how-the-web-giant-s-universe-has-expanded $>$ [Accessed 23 October 2017].

Deloitte, 2017. China E-Retail Market Report 2016. UK: Deloitte.

Doplbauer, G., 2015. European Retail in 2015. Bruchsal, Germany: GfK Geomarketing GmbH.

Doplbauer, Gerold (2016). European Retail in 2016. GfK Geomarketing GmbH, Bruchsal, Germany.

Eisenhardt, K.M. and Graebner, M.E., 2007. Theory building from cases: opportunities and challenges. Academy of Management Journal, 50(1), pp.25-32.

Ellram, L.M., 1996. The use of case study method in logistics research. Journal of Business Logistics, 17(2), pp.93-138.

Global Ports, 2012. Annual Report 2012. [pdf] Global Ports Website. Available at: $\quad<$ http://www.globalports.com/globalports/dlibrary/panda/GlobalPorts_ AnnualReport2012.pdf> [Accessed 27 October 2017].

Hänninen, M., Smedlund, A. and Mitronen, L., 2017. Digitalization in retailing: multisided platforms as drivers of industry transformation. Baltic Journal of Management, [online] Available at: < http://www.emerald insight.com/doi/abs/10.1108/BJM-04-2017-0109> [Accessed 15 January 2018].

Hille, A., 2017. European Retail in 2017. Bruchsal Germany: GfK Geomarketing $\mathrm{GmbH}$. 
Kumar, S. and Samad Arbi, A., 2007. Outsourcing strategies for apparel manufacture: a case study. Journal of Manufacturing Technology Management, [e-journal] 19(1), pp.73-91. https://doi.org/10.1108/17410380810843462.

Rashidi, H. and Tsang, E., 2016. Vehicle Scheduling in Port Automation: Advanced Algorithms for Minimum Cost Flow Problems. $2^{\text {nd }}$ edition. Boca Raton, London, New York: CRC Press.

Reimer, A. 2015. Whale of a warehouse in Narva to boost e-trade in Estonia. Postimees, [online] 5October 2015. Available at: $<$ https://news.postimees.ee/3351167/whale-of-a-warehouse-in-narva-to-boost-etrade-in-estonia> [Accessed 27 October 2017].

Republic of Estonia Tax and Custom Board, 2017. Estonian Master Tariff System. [Calculate od duties > Commodity] EMTS. [online] Available through: $<$ https://apps.emta.ee/arctictariff-public-web/\#!/taric/duty/calculate $>$ [Accessed 4 October 2017].

Salam, M.A. and Khan, S.A., 2016. Simulation based decision support system for optimization: A case of Thai logistics service provider. Industrial Management \& Data Systems, [e-journal] 116(2), pp.236-254. https://doi.org/10.1108/IMDS-052015-0192.

Sorgenfrei, J., 2013. Port Business. Norderstedt: BoD-Books on Demand GmbH.

Statistics Estonia, 2017. Ta020: Trade Enterprises, [Except Wholesale Trade And Commission Trade $>$ Turnover By Economic Activity] [online] Available through: $\quad<$ http://pub.stat.ee/px-web.2001/Dialog/varval.asp?ma=TA020 \&lang $=1>$ [Accessed 2 Novemberr 2017].

Statistics Finland, 2017. Tilastokeskus. [Turnover of trade $>2010=100$ (TOL 2008) by Year $>$ Period $>$ Industry $>$ Variable and Serie] [online] Available through: <http://pxnet2.stat.fi/PXWeb/pxweb/en/StatFin/StatFin_kau_klv/ ?tablelist=true $>$ [Accessed 2 November 2017].

The Economist, 2017. China's internet giants go global. The Economist, [online] 20 April. Available at: <https://www.economist.com/news/business/21721203tencent-leading-acquisition-spree-alibaba-close-second-chinas-internet-giantsgo> [Accessed 23 October 2017].

The Statistics Portal, 2017. Retail e-commerce sales worldwide from 2014 to 2021 (in billion U.S. dollars). [E-Commerce > B2C E-Commerce > Global retail e-commerce sales 2014-2021] [online] Available through: $<$ https://www.statista.com/statistics/379046/worldwide-retail-e-commercesales/> [Accessed 27 October 2017].

Tolli, A., 2008. Chinese container flows through Estonia to Russia and possibilities to decrease the flow of empty containers returned to China. Ph. D. Tallinn University of Technology, Tallinn, Estonia. 
Virtanen, S., 2015. Suomen Posti kuljettaa maailman suurimman verkkokaupan tilauksen Kiinasta Venäjälle ("Finnish Post transports world's largest ecommerce company shipment from China to Russia"). Tekniikka \& Talous, [online] 8 June. Available at: <http://www.tekniikkatalous.fi/talous_uutiset/201506-08/Suomen-Posti-kuljettaa-maailman-suurimman-verkkokaupan-tilauksenKiinasta-Ven\%C3\%A4j\%C3\%A4lle-3322846.html> [Accessed 23 October 2017].

Voss, C., Tsikriktsis, N. and. Frohlich, M., 2002. Case research in operations management. International Journal of Operations \& Production Management, [e-journal] 22(2), pp.195-219. https://doi.org/10.1108/01443570210414329.

Xu, X., Li, Q., Peng, L., Hsia, T.-L., Huang Ch.-J. and Wu, J.-H., 2017. The impact of informational incentives and social influence on consumer behaviour during Alibaba's online shopping carnival. Computers in Human Behaviour, [ejournal] 76, pp.245-254. https://doi.org/10.1016/j.chb.2017.07.018.

Ying, Y., Wang, X., Zhong, R.Y. and Huang, G.Q., 2016. E-commerce logistics in supply chain management: Pracatice perspective. Procedia CRIP [e-journal] 52, pp.179-185. https://doi.org/10.1016/j.procir.2016.08.002.

Zhang, A. and Huang, G.Q., 2012. Impacts of business environment changes on global manufacturing outsourcing in China. Supply Chain Management: An International Journal, [e-journal] 17(2), pp.138-151. https://doi.org/10.1108/13598541211212889.

Zhao, D., Savage, S.J. and Chen, Y., 2008. Ownership, location and prices in Chinese electronic commerce markets. Information Economics and Policy, [ejournal] 20, pp.192-207. https://doi.org/10.1016/j.infoecopol.2008.02.001.

\section{ABOUT AUTHORS}

Dr. Olli-Pekka Hilmola, Visiting Professor, Tallinn University of Technology, Estonian Maritime Academy, Kopli 101, 11712 Tallinn, and Professor, Lappeenranta University of Technology, Kouvola Unit, Prikaatintie 9, FIN45100 Kouvola, Finland, e-mail: olli-pekka.hilmola@lut.fi.

Dr. Andres Tolli, Associate Professor, Tallinn University of Technology, Estonian Maritime Academy, Kopli 101, 11712 Tallinn, Estonia, +372 5071 899, e-mail: andres.tolli@ttu.ee.

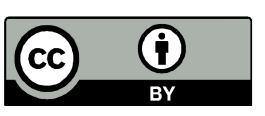

(C) 2018 by the authors. Submitted for possible open access publication under the terms and conditions of the Creative Commons Attribution (CC-BY) license (http://creativecommons.org/licenses/by/4.0/). 